\title{
Society, Socialization and Social Order through the Hindu Festivals in Nepal
}

By Bishnu Prasad Dahal

Tribhuvan University

Abstract- Festivals impart entertainment in society, people participate in socialization, and festivals act as a mechanism to resolve the social tensions, conflicts, and social stress through participation of their members. It provides a platform to express, share and understand their ideas to others through interactions. In a way, it imparts societal glue because it offers people meaning and purpose for their lives, and it gives definite values and meanings. That's why people believe in religious religions offer ceremonies and festivals socialize their members with their values, and ultimately festivals, work an agency to control the behavior of people either imparting "hope" or creating by "fear." In fact, religions, rituals and festivals are practices required or expected of members of faith and usually honor the divine power (or powers) worshipped by believers; the) also remind adherents of their religious duties and responsibilities.

Keywords: religion, ritual, festival, socialization, social order, hindu, etc.

GJHSS-C Classification: FOR Code: 160899

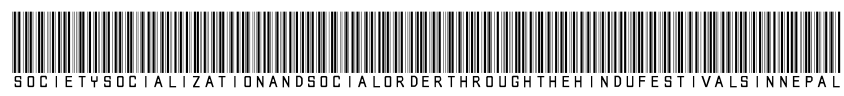

Strictly as per the compliance and regulations of:

(C) 2020. Bishnu Prasad Dahal. This is a research/review paper, distributed under the terms of the Creative Commons AttributionNoncommercial 3.0 Unported License http://creativecommons.org/licenses/by-nc/3.0/), permitting all non-commercial use, distribution, and reproduction in any medium, provided the original work is properly cited. 


\title{
Society, Socialization and Social Order through the Hindu Festivals in Nepal
}

\author{
Bishnu Prasad Dahal
}

\begin{abstract}
Festivals impart entertainment in society, people participate in socialization, and festivals act as a mechanism to resolve the social tensions, conflicts, and social stress through participation of their members. It provides a platform to express, share and understand their ideas to others through interactions. In a way, it imparts societal glue because it offers people meaning and purpose for their lives, and it gives definite values and meanings. That's why people believe in religious religions offer ceremonies and festivals socialize their members with their values, and ultimately festivals, work an agency to control the behavior of people either imparting "hope" or creating by "fear." In fact, religions, rituals and festivals are practices required or expected of members of faith and usually honor the divine power (or powers) worshipped by believers; the) also remind adherents of their religious duties and responsibilities.
\end{abstract}

The objectives of this research article is to indentify how religion, rituals, and festivals are working as a mechanism to control social behavior, how these functions in society to socialize the members and how they maintain the social order in such a diverse community like Nepal. The diversities based on religions, caste, culture, language, etc. was found in Nepal. Keywords: religion, ritual, festival, socialization, social order, hindu, etc.

\section{Hindu Society And Culture}

( espite, the diverse religious population settled in country, Nepal has not experienced interreligious conflict so far, as it had happened, and generally is experienced in many other countries. Religious syncretism, social harmony, and one respect to other's religion create the environment of social solidarity, and discard religious conflicts. No one religious community is competing with others in terms of culture and religion, though they are heterogynous. Nepal is rich in languages, and nationalities, and it has more than 120 languages, and 61 nationalities (ethnic groups). Within, such heterogeneity in a small country like Nepal, the impact of globalization is intense. Globalization is establishing global values replacing the values of ethnics and locals in one hand, and the ethnic groups have started to preserve their own cultural and religious values in another. This is clear evidence of growing awareness of ethnicity and consequence and the impact of globalization wherein people either in a group or in an individual are in search of their proper identity. Later on, the new policy has been formulated to

Author: Ph.D., Department of Anthropology, Patan Multiple Campus, Patan Dhoka, Tribhuvan University, Kathmandu, Nepal.

e-mail: phd.bishnudahal@gmail.com impart the education for those ethnic communities in their own mother tongue. It is a milestone development practices to break the monopoly of Nepalese language. Then after, other languages also have shared the pie in national broadcasting system with the incorporation of various local languages, which are major consequences of globalization and identity search in the micro level after the 1990s.

Society is always in the process of transformation. And the formation of identity takes place accordingly both at the individual level and in the grouplevel simultaneously. While talking about identity, it would be worth mentioning. He argues that the recognition of self changes during modernization, and therefore, society on a broader scale has to attempt'reskilling' of the existing recognition of self to match modernity. Modernization is a part of globalization, and we cannot avoid it.

Declaring nation as a federal democratic republic, announcing the country as secular state, integration of ex-Maoist combatants into Nepal Army, representation of women, Dalits, indigenous nationalities, and backward people in the CA are considered some of the major achievements of the first $\mathrm{CA}$. The second CA ultimately resolved the political problem nation and declared the Constitution, 2015 AD. After the promulgation of constitution of Nepal, the political discourse shifted from unstable to stable for prosperity, stability, and development of the country.

\section{a) Hindu Religion}

The diversity in geography, ethnicity, ecology, climate, religion, tradition has making Nepal diverse in culture too. The culture and tradition of Nepal is a culmination of its ethnicity, religions, values, and beliefs, tribal and social groups. Music, dance, art, literature, folklore, and its language reflect the rich and the diverse culture. It is a showcase of what the Nepalese lifestyle has to show and offer. Culture in Nepal is a symbol of the nation's wealthy, harmonized, and diversified society (Bista, 1991).

A festival is a special occasion of feasting or celebration, usually with a religious focus. Aside from religion, and sometimes folklore, another significant origin is agricultural. Food (and consequently agriculture) is so vital that many festivals are associated with harvest time. Nepal has been a cultural, spiritual, and religious hub of eastern civilization of Hinduism in one hand, and in other hand, the place of origination of 
Buddhism for millenniums. Today, the country is secular, religiously harmonized, amalgamated, assimilated, and gives utmost respect and recognition to over a dozen religions, celebrating the origin, tradition, customs, heritage, and teaching of every worship, and faith with great pride. Thus, the country delights, and rejoices unique festivals throughout the year, with most of these festival traditions dating back to medieval times.

Since the declaration of secularism, Nepal welcomes new religion, and the assimilation of various faiths, beliefs based on religion help to make the country religious, and cultural diversity. Since, ancient times Hinduism was established as the dominant religion, and $81.3 \%$ of the total populations of Nepal were Hindus, and the beliefs system largely influences the culture and tradition of country due to the sheer number of followers of Hinduism. Similarly, Buddhism stands as the second largest, and dominant religion with $9 \%$ of the total population. The rest of the community follows Islam (4.4\%), Kiratism (3\%), Christianity (1.5\%) and others (0.6\%) (CBS, 2013).

Nepal is the country of verities of cultures, religions and festivals observed throughout the year. Being conglomeration of Hindu, and Buddhist communities, most of the festivals are commonly organized, and both of the believers, celebrate, and participate the assimilated cultural festivals together with full of harmony, and joy. The perfect blending of faith, beliefs, customs, and traditions among the followers of these religious groups are truly a wonder. Many forms of Buddhist deities, and Hindu deities, are kept in same temple too because of their interconnectedness and interrelations. The followers of both religions equally respect the deities and worship them, and the harmony, and feeling of brotherhood that exists in the Nepalese culture. Both Hindus, and Buddhists celebrate Dashain harmoniously; taking blessings from elders is an absolute necessity as it is a part of the culture of Nepal (Bista, 1969). People from different places return home to celebrate the festival with their families in Dashain, and it are also known as the festival of reunions. This festival marks the victory of good over evil, and it is celebrated with families, and with kin, full of joy, and happiness. Likewise, in reference with Dashain, the celebration of festival Tihar, has its particular significance in society, and is also known as the festival of light at that time the environment is exceptionally bright and festive. It recognizes the importance of animals in their ecology for their services. Similarly the people from the Terai region worship the Sun, in this festival, which is known as Chhath. It is to thank the sun for sustaining life on earth. Likewise, the people from the hill and mountain regions also celebrate the Tibetan New Year as Losar, three times in a year for Gurungs, Tamangs, and Sherpas.

\section{b) Social Structure and Social Conflict}

The country is rich, and diverse culturally, linguistically, religiously, and in terms of ethnicity too. The nation has number of socio-cultural, and ethnic groups with diverse language. The unique dress patterns, different food habit and following different beliefs system are also the additional features of the country. Although the country has its distinct identity of a multi-cultural, multi-ethnic, multi-lingual, multi-religious nation, and these diverse groups are united under the same identity of being a Nepali. Due to the blended, assimilated, and enriched practices, and social systems, cultures are more flexible, adaptable, dynamic, and harmonious too. People change the traditional practices, rules, regulations as per their need, and necessity in society.

Society in Nepal never felt equal, and stratified in terms of caste, ethnicity, class, religion, language and gender. The higher caste, and class people have enjoyed more facilities than those of the lower. Despite diversities, in many cultural and ethnic groups in Nepal, they always live in collectively, and harmony with each other. There are high degrees of tolerance among the various cultures, and no disputes of them permit to grant the cultural solidarity of the country. Nepalese society has vertical, and horizontal stratification in terms of caste, class and gender and horizontally in terms of religion, and culture with mixed culture. Although there reside different cultures intermixed with other cultures, cultures that are diffused, modified, and adapted as new culture mixed up with traditional values. People are free to choose their cultural practices, and no one force to follow a particular format, that's why, Nepal is in the transition phase in terms of its politics, society and culture as well.

Nepal is a melting pot of Hindus and diverse ethnic groups for long. Such contact gives rise to unique features which only can find in the nation but rarely in others. Interaction between these diversified groups develops the social relationship between these various groups so that the so-called "Hindu-Tribal" relationship in Nepal has never been characterized as one of the total isolation, either in the past or in current times (Nepali, 1967).

The main concern is that conflict theory generally focuses on social structure (i.e., relationship); but not pays attention in actors, their thoughts, and action. Actors as a high caste Hindu Brahman and Chhetris or Thakuris, their concepts as conservatively as well as resources of those with whom they are dealing (chakari) or traditional values, static system, fatalistic ideologies, and people act the chakari and the afno manche as the practices in Hindu society. A parallel with Collins, Bista finds the Nepalese people want to maximize their subjective status, and the ability to do as depends on their resources, and authority as well as the 
resources of those whom they are dealing (chakari). Bista found people as self- interested and clashed (modern Vs traditional) are likely to occur because sets of interests (to do chakari to make afno manche and to achieve results fatalistically) may be inherently antagonistic (Bista, 1991).

Social conflict arose by development, modernization, etc. within the framework of a structuralfunctional view of the world, i.e., from the traditionalism, chakari, fatalism, and afno manche, etc., and every activity related with conflicts ultimately provides the positive functions in every society, in contrast, the conflict of interests and groups for the betterment or change of the traditional practices, norms, values, attitudes, ascribe social value, division of labor, caste system, Hindu religion, family structure, and socialization; culture and personality system, education system, i.e., Sanskrit Education and politics, etc. as the hindering factors for Nepalese development (Bista, 1991).

Childhood socialization among the higher caste
groups centers on the appreciation of caste distinctiveness and the gap between different caste groups as well taught. Hindu ideology is that ideology that teaches the concepts of "should do" and "should not do" rigidly. In Nepalese society, family never stands as the socio-economic-political units. Despite this, the family functions as the socialization of Hindu values, norms, and perceptions as the primary agents. After then priest caste, boys go towards the herding cow, goats, sheep, and cattle, but they never engaged in other productive fields (i.e., acquiring higher productive education-technical, other than Sanskrit, which is unproductive jobs). Instead, they were taught by their fathers to be literate in Sanskrit, and educated the ritual activities of their priestly call options, other than that. The Priesthood is slim, and other administrative jobs can core by only if the family is favorably positioned with people in authority. Priest as a ritual teacher and the action taken by him is the social actions in Hindu society (Bista, 1991).

\section{c) Festival}

Festivals are the most important institutions of Hindu society, for it is their own distinct identity. These celebrations reinforce the group's solidarity at different levels like caste, patrilineal group, and family, kin. Feasts elaborate and an extravagant affair among groups during celebrations. The merit making, fun, and joy (recreation) helps in tension management while its latent function is to provide food that is rich in nutrients like meat, grains, sweets, etc. Hindus are laborious workers, and they need rich, and balanced diet. Festivals help to maintain solidarity on four different levels that are through; family; the occasions, which are celebrated in family level only-like, "Mha Puja," "Kija Puja," Maker Sankranti,". Janai Purnima," etc.
In the festivals, which are celebrated in patrilineal grouping level only like; Dewali Puja, ancestor lineage worship, or Shradh. These festivals appear to be some dead ancestor whose identity has been antiquity. The manifest function of the Shradh is to get a blessing from Shradh. At the same time, it's latent function it is to provide solidarity to the patrilineal group and offer reunion of its members. Similarly, the festivals, celebrate in caste groups level only like caste, Sana Guthi, in festivals Nag Puja, Holi, Dashain, etc. But, celebrations like Bhairab Jatra, Gai Jatra, Machindra Jatra, Kirshna Jatra, Ganesh Jatra, etc. these keep different groups in touch with each other and help in maintain harmony at the regional level.

Dashain is the great festival of Hindus in Nepal consists of the longest and the most auspicious festival in the Nepalese annual calendar, celebrated by Nepalese Hindu people throughout the globe, which is most anticipated. The festival lies on September or October, beginning from the Shukla Paksha (bright lunar fortnight) of the month of Ashoj, and ending on Purnima, the full moon.

Another famous festival celebrates five-days known as- Tihar, in general, signifies the festival of lights, where diyos are lit both inside and outside the houses to make it illuminate at night. It is considered to be of great importance as it shows reverence to not just the humans and the Gods, but also to the animals like crow, cow, and dog, who maintain an intense relationship with the humans.

Chhath is another festival of Nepal celebrated by Hindus of Mithila region, Maithali Tharus indigenous people, including others in Kathmandu. It is a festival of Hindus dedicated to the Sun as form of Hindu God, named as Surya Bhagwan, and Chhathi Maiya (ancient Vedic Goddess Usha). The Chhath Puja performed to thank Surya Bhagwan for sustaining life on earth and to request the granting of blesses, and wishes.

Similarly, Hindus, and non- Hindus like Buddhist, Jain, belonging to Omkaar family celebrate Rakshyabandhan or Janai Purnima which takes place on the full moon day of Shrawan Purnima every year. In Janai Purnima, Brahman priests offer an ornamental thread to the wrists of their followers and in return receive gifts, while Buddhist bath in sacred streams and visit their temples, and the many pilgrims. Mainly the male Brahmin, and Chettri community change the sacred around their neck. Similarly, the worship of Nag in Nag- Panchami, protects from snakes biting because there are few snakes inhabiting Nepal. The ecological importance of nag in agriculture an important species in eco-cycle and food chain also paid values culturally. The Nag-Panchami is the day of welcoming the other festivals in Nepal.

Other festivals like, Krishna Janmashtami, Gai Jatra, Losar, Bisket Jatra, Bajra Jogini Jatra, Makar Sankranti, Sito Jatra, Ghanta Karna, Bala Chaturdashi, 
Indra Jatra, Kartik Purnima, Ganesh Chauthi, Maghe Purnima, Ghode Jatra, Rato Machhindra Nath Ko Jatra, (Bhoto Dekhaune), etc.

Socialization, in the most general sense, is the process through which individuals acquire the knowledge, skills, and integrate into society through various agencies such as family, peer-group, and educational institutions necessary to enable them to interact with others. Socialization of children possesses ability to imitate, and the family provides supportive conditions in which customs, values, and traditions learn through imitation. The real human life is the process of socializations either in individual level or in a social level through which, human develops the ability to control him or herself and helps him/her to realize his/her responsibility towards family, community, and society. The persons makes society that would strike many as a startling notion, though, I know of no good reason for looking upon the distributive aspect of life as more primary or causative than the collective, and the self, and society are two sides of the same coin. The individuality is neither prior in time nor lower in rank than sociality; but that the two have always existed side by side as complementary aspects of the same thing, and that the line of progress is from a lower to a higher type of both, not from one to the other. In the course of learning a human borrow his or her ideas, loyalties, attitudes, and points of views that derive from others. One means of their transmission is, as Cooley called it, the 'looking-glass self (Cooley, 1998).

According to G.H. Mead, the individual's role means to get a picture of him by playing the roles of others. The individual is putting himself in the place of others and imagining what their response might be. The 'others' his parents, close associates, and, finally, society itself. When the child gets older, he or she observes to act towards its dolls or toys as the mother or other members of the family have acted towards him. The child at play is taking on the role of another person through 'role-playing' (role of the mother) father or other persons; the child is enabled to see himself objectively through the eyes of others. Of these 'others,' some are more "significant" (Mead, 1938). The self is not the thing that exists first with him, and her, then in a relationship with others. The 'self' is a product of social interaction. 'It arises in social experience.' The growth and development of self is in a social context.

\section{Theoretical Overview}

The religions bring people together in family, community, and regional, national, as well as at the international level. Religions give rise to different festivals that are very much important for tension management and integration. Festivals offer inter-caste participation based on locality, whose function is to create, on the other hand, it confined to the household or in the community help to create solidarity among the kin and family as a whole. Religion is autonomous, and sui generis; it arose from a welter of sensory and psychological factors. The feeling and imagination which in the religious world are bound to theological belief have to attach themselves to a positive natural philosophy, and a positive morality (Tylor 1958 II).

According to Durkheim, people tend to separate sacred and profane religious symbols, objects, and rituals from the daily symbols, objects, and routines of their religious life. Sacred objects those are divine properties that separate them from profane objects. Even in more-advanced cultures, people still view sacred objects with a sense of admiration and amazement, even if they do not believe on some power. Religion concerns more than belief but also encompasses regular religious ceremonies on the part of a group of believers, who then develop and strengthen a sense of group solidarity. The functions of rituals are to bind the members of a religious group together, and they allow individuals to escape from the mundane aspects of daily life into higher realms of experience. Sacred rituals and ceremonies are especially for marking occasions such as rite of passage; births, marriages, times of crisis, and deaths (Craib, 1997).

Religion exemplifies how functionalists examine sociological phenomena and religion functions to bind society's members by prompting them to affirm their values, and beliefs regularly. The scientific thinking would likely replace religious reasoning, with people giving only minimal attention to rituals and ceremonies. Now, the concept of "God" is in the verge of extinction, and society promotes civil religion, in which civic sense and celebrations, parades, and patriotism take place gradually. This belief system used to continue. However, it would do so only as a means to preserve social cohesion and order.

Studying society a parallel with elaborating natural and human worlds the logical explanation is necessary so as to study scientifically. The logical mind specialized to the point where logic penetrates our conceptions about the world is inchoate, and not sharply specialized, and the mind can only penetrate the natural, and human worlds with the help of the directives of religious representations. Every religion aims to procure salvation-salvation as the transcending of present experience, away from the distress of experience, the attaining of an idealized sphere. Salvation according to Durkheim is the aim that accounts, within and for the individual, for the fact that the only way he can pull himself out of himself, the only way she can rise above her present condition of needful being, is to live as a social being (Craib,1997). Salvation, then, is a kind of socialization of the individual within the sphere of the ideal, into what society can procure for him in the way of transcendence. But transcendence is 
not as an abstract idea, but lived transcendence, transcendence through action, access to a type of in which the individual feels he or she is "stronger," capable of more than he or she can do individually.

The human action can revive, revitalize, the society, and in any kind of tensions that, conversely, such action is what enables society to exist and maintain its order through the mechanism religion. Social agents nurtures, and nourish the individuals through religion, and person or members of institution can get an experience of something greater. It offers ideal life, values, and norms as the aim of his life, and to sustain these system, one should act his or her action, to make good conquest over evil - the justice, which is intrinsically social because there can be no other justice than a society which we have made better than the one in which our present life unfolds (Durkheim, 1947).

Max Weber propounded the macro level of study of religions around the world to discover the impacts of religion on social change. In Protestantism, especially the "Protestant Work Ethic," saw the roots of capitalism. In Eastern religions, like in Hinduism, there were barriers to capitalism by emphasizing attaining higher levels of spirituality and escaping from the unproductive, irrational hard work in the physical world to create money, and resources. According to Weber, the Christianity is that salvation religion saves the life of people, and when people follow the beliefs and moral codes, the idea of "sin" and its atonement by God's grace plays a fundamental role (Weber, 2009). Unlike the Hindu religions' passive approach, salvation religions in Christianity are active, demanding continuous struggles against $\sin$ and the negative aspects of society.

While people do not understand society, so they project their own culturally- based norms and values onto separate entities such as gods, spirits, angels, and demons and after humans realize that they have projected their merits onto religion, they can achieve these values in this world rather than in an afterlife (Feuerbach, 1957). Similarly, Marx once declared that religious faith is the "opium of the people" and the religion as teaching people to accept their current lot in life, no matter how bad, while postponing rewards and happiness to some afterlife (Raines, 2002). Religion, then, hinders social change by teaching acceptance to oppression, distracting people's attention away from worldly injustices, enhancing inequalities of power and wealth for the privileged and emphasizing rewards yet to come, as a sanctuary from the harshness of everyday life and oppression by the powerful.

Marx endorses Feuerbach's view of religion as factor of alienation, and he coined the term 'alienated consciousness' in spite of religion because it is reactive phenomenological reflection of a more basic brutalizing alienation in socio-economic sphere of human life. Religion reinforces the socio-economic arrangements by consoling the oppressed and convincing their oppression especially based on their fate. In this regards, Freud's "psychoanalytic" theory emphasizes on the misconception fulfillment of powerful wishes for a protector, and as a symbolic enactment of ambivalence about the father. Freud prevaricates about the historicity of this oedipal conflict based on psychology. He portrays the primal crime is product of either historical phylogenetic truth or is an illustration of a universal psychological conflict.

Rituals are understood as mechanisms to encompass societal harmony, solidarity, and unity, although according to Gluckman (1954), this unity may be achieved despite social conflicts, and competing for social norms, and values. Not only religious functions, rituals acts as political and legal-judicial mechanism or processes as mere compensations, or redressive mechanisms for the tensions produced in the secular order. Rituals, performed by cult-associations crosscutting the boundaries of lineages and villages, creating networks of association, were treated as merely the "social glue" that holds Ndembu society together (Turner, 1967). Ritual has a function to fulfill, and the ritual system compensates to some extent for the limited range of effective political control and for the instability of kinship and affinal ties to which political value is attached (Turner, 1967). Similarly, the role of rituals is to sustain a society's equilibrium and secure solidarity among its members and a profound interest in the theatrical and creative side of man (which also provided the name for his conceptual tool of social "drama"). Human creativity like art, literature, and poetry are also their lifelong interest but not the ritual.

Ritual provides the prescribed formal behavior occasionally not regularly but, it refers to beliefs in mystical beings and powers and a symbol is the smallest unit of ritual which still retains the specific properties of ritual behavior; it is a "storage unit" filled with a vast amount of information (Turner 1968a). Symbols may represent objects, activities, words, cultural artifacts, relationships, events, phenomena, gestures, or spatial units (Turner 1967). Ritual, religious beliefs, and symbols are related. Ritual is "a stereotyped sequence of activities involving gestures, words, and objects, performed in a sequestered place, and designed to influence preternatural entities or forces on behalf of the actors' goals and interests" (Turner 1977a) and they are depository of meaningful symbols through which cultural life of people identified, disclosed, and regarded as authoritative, as dealing with the crucial values of the community (Turner 1968a).

Life-crisis rituals refer the transformation of one phase to another, and are important in the physical or social development of the ritual subject, such as birth, puberty, or death. In Ndembu society, life crisis-rituals include initiation ceremonies for boys and girls and funeral rites. Rituals of affliction are performed for 
individuals who are "caught" by the spirits of deceased relatives whom they have forgotten or neglected ritually in their ceremonies. Those spirits (Turner [1967] uses the term "shades") may afflict the Ndembu in three ways: first, fail to find animals to shoot, or drive animals out of range by the shadow of a hunter, may cause his kin to miss their aim. Similarly, the shadow of a woman may cause her kin to have reproductive troubles. Lastly, the shadow of both sexes may cause their living kin to become ill in various ways. In conclusion, Ndembu rituals can understand as hunters' cults, women's fertility cults, and curative cults. Hence, Ndembu rituals are associations of cults on behalf of beliefs of persons believed to be afflicted by a shade (Turner 1968a).

A parallel with Levi-Strauss, "religion in action," is for human action, and its manipulation. In Turner's perspective it is ritualistic, since it is studied primarily through the analysis of ritual, while in the course of an elaborate systematic treatment of Ndembu society, religious thought is lacking. Religion is "regarded as something apart from our economic, political, domestic, and recreational life. Religion is part of the division of social labor" (Turner, 1976). Modern religion, since the industrial revolution, and because of the processes of institutionalization and secularization, has aloof from the rest of culture.

Usually, sphere of human life such as; religion, economy, law, politics, and other cultural domains interweaved with each other. Rituals may take place in either one of these institutional domains, or not always with religious connotations, since they may happen outside the realm of institutionalized religion where matters of the "supernatural" do not explain. Rituals are also secular, this-worldly rituals in tribal societies (although not as many as in the industrial world), and that therefore ritual should be studied in terms of the socio-structural environment regardless of references to the supernatural (Douglas, 1978).

\section{ili. Methodology}

Methodologically, festivals are the part of sociocultural phenomena, and within these cultural practices in the base of religion, there are many functions of festivals both manifestly or latently. In anthropology, I have used ethnographic study with participant observation methods to identify the significance of socialization, and festivals to maintain social order in Nepal where dominant Hindu religious people with other ethnic and religious people celebrate their various holy festivals throughout the year. In such a situation, and condition, these non-Hindus can take part in these festivals with ignoring processes and function of worship, still they follow and celebrate for the entertainments, meal, and they enjoy the holidays, and other facilities while providing in the name of such ceremonies.
I had conducted this research in Kathmandu in the whole year of 2019; during study, I have collected both quantitative and qualitative data through; openended interviews, structured interviews, and semistructured interviews. The key informants varied the data of cultural festivals in Nepal. The researcher is also a member of the society where the cultural festivals are celebrating every year, as a participant- observer researcher has tried to maintain the ethics to easy to visualize the cultural processes without bias. It has also helped to explore the reason behind the social structure, socialization pattern, and celebration of festivals.

Based on the criteria for the selections of respondents were the participants of festivals this year, and it is a big challenge to gather the information about festivals through the same participant in festivals of a year. That's why; specific respondents were selected for a specific festival to accomplish the research. This information on maintaining confidentiality was provided from the respondent both orally as well as through the information sheet. I have preserved the identity of respondents and their settlement by using pseudonyms. I have changed the identification details of the participants, such as their field of work and studies, to preserve their anonymity.

Interviews were conducted to both participants and observers about the festivals, its history, and community from where they are participating; a society where they live, etc. and I had conducted the interviews in the Nepali language with respondents of participants of festivals through which can generate the information about festivals and their cultures. The rest of the information about festivals like; management, involvements, and its significance were gathered from senior persons who had involved in festivals. Similarly, I had asked many researchers and cultural experts about the particular festivals, their interconnections, and interdependence with other factors of cultures.

\section{a) Participant observation}

Purposively Hindu festivals Dashain, Tihar, Krishna Janmashtami, Gai Jatra, Bisket Jatra, Bajra Jogini Jatra, Makar Sankranti, Sito Jatra, Ghanta Karna, Bala Chaturdashi, Indra Jatra, Kartik Purnima, Ganesh Chauthi, Maghe Purnima, Ghode Jatra, Rato Machhindra Nath Ko Jatra, (Bhoto Dekhaune), etc. were listed out and among them Dashain, Tihar, Krishna Janmashtami, Gai Jatra, Bala Chaturdashi,, Indra Jatra, Rato Machindra Nath Ko Jatra, (Bhoto Dekhaune) were selected an analytical unit to easy, and valid to elaborate, and juxtapose the festivals events, and festivals have maintained the social order and it visualized how the how cultural socializations are taken placed. Researcher is also a member of the society where the cultural festivals are celebrating every year. 


\section{Findings and Discussion}

Given cultural anthropologists' perspective, society is a web of relationships of different people with different behaviors. The society comprises diverse components but is opposite, and their nature unites to perform task and function. In this study, respondents were given a clear version of the how festivals help to resolve the tensions, how festivals impart the cultural values through the socializations, and how is in order despite the diverse elements.

\section{a) Threats of Family and Marriage in Hindu society}

In Hindu society, "marriage" as a problem in Hindu life because after marriage, joint and extended family types, may breakdown, the property will share, the land will fragment, and marriage produces children and higher the number of children, less is the accessibility or availability of the economic and environmental resource, social status, etc. In Nepal, traditionally, the basic unit of Hindu Society was not the individual but the joint family. A joint family is a group of people who generally live under one roof, who eat food cooked in one kitchen, who hold common property and participate in family worship and are related to one another as some particular type of kinder (Karve, 1953). Still, now a day in Nepal, it is completely changed, because of the urbanization, individualization, influence of Western culture and their value system it has been changing day by day.

In a joint family, respects, reorganization, fear, and affection between the father and son, mother-in-law, and daughter-in-laws determines the relationships. The feelings towards the parents either mother-in-law or father-in-law were so strong that an affective bond was created. The acceptance or rejection of decision on household chores, to follow traditional values and norms and celebration of feasts and festivals including the worship of parental deities, etc. creates opposite poles inside households in one hand and due to the lacks of time to spend in the household because of heavy work to sustain their urban life creates gap between two generations. In some cases, it is found that the pattern of family life is changing, and parents become more liberal in the upbringing of their children. As a result, parents find that their children do not have the same attitude and values with which they were brought up.

Consequently they find themselves unprepared and at a loss for as to how they must grapple with the problems they face in relating to their unstable and expressive adolescent children. They often tend to retreat into the security of tradition and conventional patterns of parental authority, which only creates more tensions. In this crucial stage of transition, in most of the families that we found, the severe family tension, stress, family misunderstanding, and, in some cases, ready to explode. The trend of young male migration shows as the evidence for it even though they have opportunities in the mother land.

That's why the younger generation today is subjected to pressure and anxiety due to the rapid changes and intense competition in the professional field, and they are highly stressed in household chores due to social, cultural, and economic reasons and Nepalese society is at the crossroads. The process of industrialization, urbanization, and modernization, impacts on the verge of changes in traditional institutions and organizations like the joint family, caste, kinship group, and religion have lost their original significance and hold on the youth to a considerable extent. In both households and the public sphere, the youth are disappointed with the irrational, unscientific, unplanned, unaccountable, corrupt, and discredited authority. Corruption, the craze for power, moral lapses, opportunism, nepotism or favoritism, discrimination, etc. in the political-economy, and psycho-social sectors of leadership have made the youth to have nothing but dislike or contempt for them, and they want to go abroad for their future career.

The institution of family in Nepal, unlike in the west, has been shown by several studies to be intimately linked with its kinship and, the caste system in its societal aspects, and occupational structure in its economy. The kinship and caste structures are changing under the impact of Industrialization and modernization. The traditional links between caste and occupation are fast disappearing. Also, the diversification and secularization have increased in recent times in Nepal. In the present day educated family, the husband and wife have an almost equal share of participation in family interactions and decisionmaking. This near-equality of the sexes within the family and sharing of household work and other responsibilities combined with their new liberal outlook and modernization has a significant and positive impact on the socialization of the child.

So, perfect parent's sex brings marriage, and marriage seems exciting, but this pleasure will not last further. Marriage brings children, and children to bring joy but children fail to reciprocate in one's declining years. Similarly, children's poses a threat at various levels in Hindu society as; for mother, rupture of the compassion bond in one hand and hard economic realities labor decreased, property (land, house, ornaments, house utensils) divided and cattle shared. Likewise, fragmentation of land on one hand and disorganization of familial level production unit ultimately increases the household expenses in others severely stress on an old couples who are dependent on the son. The friction of mothers-in-law, and daughter-in-laws polarized the once unified and integrated household unit of production into the opposite poles. Such a crisis of children's marriages and problems of the aged in Hindu culture is a crisis of personal identity as well as survival. 
All these issues were resolved in Hindu society by the symbolism of the festivals like Dashain (bond within consanguine kinship-Intra consanguine kinship, and then with others, i.e., inter affinal for generations), Tihar (bond between native and affine home), Janai Purnima, etc.

All these problems related to the household chores are resolved by offering various rituals: some of them are by Dashain, some of them by Tihar and rest are by other festivals like Janai Purnima. Symbolically it involves extreme condensation of complex and profound feelings and meanings. Festivals transform from the worldly material life to the merits of the spiritual world and socialization within families with their roles and responsibilities.

\section{b) Society and Land Fragmentation in Nepal}

Land as an economical means consists of ordering and organization of human relations and human effort to procure as many of the necessities of day-to-day life as possible with the expenditure of minimum effort. Land provides maximum satisfaction through adaptation limited means of unlimited ends (needs) in an organized manner. The land is an essential natural resource that is an important resource for food, shelter, and clothes, for the survival and prosperity of humanity and the maintenance of all global ecosystems (FAO, 2008). Land fragmentation is a phenomenon that exists when a household operates several owned or rented non-contiguous plots at the same time (Wu et al., 2005). One of the reasons of land fragmentation in Nepal is because of family fragmentations once from joint family to nuclear family because of parental property rights.

The existence of fragmented land holdings is regarded as an important feature of less developed agricultural systems. The main factors triggering land fragmentation are inheritance; population growth; land markets; and historical or cultural background (Van et al., 2007). Land, traditionally used for agricultural purposes, has, over the years, been fragmented as a regular phenomenon for various reasons (Shrestha, 2011). Fragmentation is also a common characteristic of land in Nepal. People have the right to sell and buy private land in any part of Nepal, and parcel fragmentation is resulted due to the continuous land transaction. By inheritance provision of equal division of property among sons and recently to daughters also caused fragmentation of land. The structure of the land inheritance system, haphazard housing and urbanization planning, and loosely-enforced policies are all responsible for land fragmentation in Nepal (CRSC, 2012). Land fragmentation is rooted in traditional inheritance practices whereby the parental estate is divided equally among sons (Sapkota, 2004) which are considered as a obstacle to agricultural mechanization, causing inefficiencies in production and involves cost to alleviate its effects in Nepal also (Niroula \& Thapa, 2007).

The land fragmentation and land registration provisions ultimately promote the land transfer from Guthi to Raikar and the big chunks of lands in one hand degrading day by day and the institutions of Guthi which are the heart of maintaining festivals are also weakening day by day because of financial as well as the conversion of agricultural land to the residential purpose. Such Guthi organizations especially established for rituals of particular festivals thus sets up a network of the social relationships involving values, norms, etiquette, and social precedence based on age and generation. It is also a working organization concerning the social and religious interests of its member. The Sana Guthi and the Dewali Guthi function as the most effective instrument of preserving caste norms, religions, rituals to maintain the harmony, cohesion, and social solidarity (Nepali, 1967). Such institutions like Guthis have unlimited functions in numerous inter-caste relations involving the solidarity of regional communities where they celebrate festivals together.

The ritual, festive and social life is regulated and controlled through the "Guth" institution in the case of some Hindu community and people in Nepal. A network of such "Guthi" institutions binds those communities together at different levels. The Guthi's manifest function is to fulfill material (e.g., feast), and religious (e.g., funeral) interest, but its latent function is to preserve norms and values of the community. But, due to the industrialization, urbanization, and globalization, the trend of transformation of communities and homogeneous societies to the heterogeneous societies led the situations "verge of collapse" of such ritual, festival oriented and social institutions along with the land use pattern, land holdings, land as property rights and a unit of productions ultimately creates the obstacles to the offering, celebrating the feasts and festivals in Nepal directly or indirectly hampers the cultural socializations, imparting the cultural values, norms, and ultimately hampers the social harmony.

\section{c) Ancestral Worship (Shradh) and Kinship Bond}

Lineage worship or Shradh appears to be some dead ancestor whose identity has been antiquity. The manifest function of the lineage worship or Shreadh is to get blessings from ancestors, while its latent function is to provide solidarity to the patrilineal group and offer reunion of its members. People worshiped their ancestors in Shreadh, and prayers offered for the repose of their souls, which is assumed more merit making than the worship of God because a person owes his physical birth to his lineage. The religious text Karam Kand (which emphasizes homage to ancestors) recommended the Shradh, and observed from the autumnal full moon to the following Aushi (night) for 15 
days. On Aaushi day, the worship is to unknown ancestors. The period starts with Parewa, Dwitiya, Tritya, Chaturthi, and so on, for the full fortnight and a day.

It is believed that ancestors appear in dreams, to warn of impending dangers in the coming year, during Shradh, in Hindu mythology, each day of the Shradh is equal to a year, and so the multiplication goes on to includes all ancestors for 15 generations and beyond. Ancestor worship starts with the father and mother. It includes grandfather, grandmother, greatgrandfather, and great-grandmother back to as many generations as one can remember, with reverence paid to both paternal and maternal ancestors. For the unknown ancestors, Seedha (raw) food is offered in a Thali that includes wheat flour, rice, kheer (milk pudding), and sabzi (vegetables).

The Shradh begins, when prayer shaved his hair, took holy bath and stayed fasting before the Shardh day, and it is believed that it is known as the Aushi bath. The other days are utilized for offering prayers to ancestors, in which lies Moksha (salvation), both for those performing the rituals and for the long departed ancestors. It is believed that any one Hindu must pay the three different loans- Pitri Rin (Loan of ancestors), Dev Rin (Loan of Gods), Guru Rin (Loan of teachers). Loan of ancestor is paid when the departed souls of get salvation, present generation may fulfill the desires of all kinds and when he or she will give proper guideline to new generations.

On the occasion of Shradh, patrilineal kin's are invited to offer tika, Prasad, and meals. The invitees may be the members who born in the same patrilineal kin's, their daughters, and her family members. It also stands as the kinship terms, family bond, kinship relations, and their degree, etc to respond and associated with their kin groups to maintain familial bonds.

d) Offering Festivals: Cultural Socialization, Tension Resolutions, and Social Harmony

Religious festivals are the cornerstone of these public and private reunions. Still these last-mentioned are embodied in a plethora of forms of ritual, worship celebrations, and social interactions in the cultural milieu.

Moreover, Krishna Janmashtami, Gai Jatra, Losar, Bisket Jatra, Bajra Jogini Jatra, Makar Sankranti, Sito Jatra, Ghanta Karna, Bala Chaturdashi,, Indra Jatra, Kartik Purnima, Ganesh Chauthi, Maghe Purnima, Ghode Jatra, Rato Machhindra Nath Ko Jatra, (Bhoto Dekhaune), etc. festivals that are celebrated in various places of Kathmandu valley as some of these festivals stand as national festivals, some are as regional, and some as local place, festivals associate with specific places-, with temples, god, the goddess associated with particular Guthis to organize, celebrate and commencement of these festivals. It is very difficult to declare the exact number of festivals celebrate in
Kathmandu every year, because all festivals are not annual only. Some festivals are very special which are organized in the interval of five, twelve and twenty years of interval.

Among annual festivals of Kathmandu valley most of the citizen will participate as soon as possible in individual level, but in some cases, the groups, organizations, institutions also took part in festivals as a member of that organization. The Bhoto Dekhauni Jatra of Rato Machhendranath takes place every year in Patan as a strictly local as well as national festivity, running exceptionally at the moment as. In this festival, huge cart with special architect is designed to put god inside and mass people pull and push the cart to travel and roaming around the ancient cities of Patan. The festivity help to teach the cultural values along with fundamental cultural components associated with it can easily transfer to new generation through participation with full of joy and happiness. The ritual's majesties (some would say immoderate) lie in being one of the longest festivals in the world. it runs for the length of the event, i.e., two to three months, notably during the Rath Jatra, which consists in manually pulling across the city a 52-feet-tall chariot with ropes and a lot of will power, in honor of Machhendranath, goddess of rain, to ensure fertile precipitations during the near-following monsoon.

Such type of public sphere is necessary for social and cultural interaction and socialization in every society and country. It means that the social, and cultural values of the public life simply takes place in such culturally rich country like Nepal, where the public locations, and this kind of simplicity has not been conserved for various purpose the most important purpose is to interact large number of people culturally in the occasion of festival. In case of the western, the social aspects of existence would occur in private and defined places, at restaurants, clubs, pubs, and cinemas. Still in case of Nepal, every festival has its great significance in terms of social interaction and cultural socializations of norms, values, traditions, customs, etc. in a way it, and it has also kept its most religious aspect in free-access-to-all such public spheres like temples, Nasal, Chowk, Dabali, etc. before the festivities then move (and stay) in the streets, privileged for joy demonstrations, dances, songs in one to impart joys in their material world, and in another hand it enforces harmony, cohesion, and solidarity.

In the case of the Dashain festival, the social function of the Dashain is, in fact, the ceremony of reunion and fun. People living far away from home or homeland, revisit their home and get together with their families and kins. Similarly, parents buy new clothes for their children. People invite guests, organize a feast, visit their relatives' houses, fly kites, build bamboo swings and get involved in various entertaining activities. They also have great practice of a custom called Mwohni. It is important for them because it emphasizes the family 
gatherings as well as on a renewal of community ties. The specialty of this gathering is offering a feast and through which they want to introduce their families with guests, kin's and relatives, through a special dinner called Nakhtya, and various community processions of deities called Jatra is also done throughout the three cities of Kathmandu Valley.

In Hindu Mythology, there are various beliefs regarding the celebration of Dashain and its significance. However, the beliefs of this festival are that good always wins over evil. It is mythological beliefs that there is the demon Mahishasur created a terror in the Devlok (Heaven or the world where Gods live). Goddess Durga on behave of gods killed all his demons and Durga defeated the demon Mahishasur in the tenth day which is named as Bijaya Dashami. The first nineday of Dashain the battle is one of the components of the festival. The battle between the different manifestation of Goddess and Mahishasur, symbolized the victory of truth over evil, as in the Ramayan. The festival is celebrated to mark the victory of Lord Ram over Ravan, who kidnapped the wife of Ram named Sita. Now, moving towards Buddhism, Nepalese Buddhists also celebrated the festival of Dashain to honor the adoption of Ahimsa and Buddhism by the Ashok, the Indian emperor.

In a way, Dashain enhances social solidarity; social cohesion helps to reduces the familial tensions, stresses, and conflicts, which helps to strengthen the social relationships, social bonds, and among and between stakeholders and kins. It also helps to promote social, ritual, cultural interactions, and socializations to all members of the society. In the case of Tihar, festivals, ceremonies, worships, social gatherings, social interactions, etc. happen, are observed by members of society in which new members can learn more from peers, their parents, their relatives through the participation. In this regards, everything is managed, brought to play the necessary and appropriate devotion without any consideration for the happiness, joy and celebration of this festival.

Similarly, from the Teej festival, women in a sari who have not eaten anything for the day will simply wait to enter the Pashupatinath temple, even if they have to be patient for four hours. Likewise, in the Rato Machhendranath festival, which will last for two or three months, the only imposition will be to complete the journey of the carriage across the city.

Thus, the potential social disorder that might be created by "victory of evil to the truth" or "Ravan to Ram" is overcome by the rituals of Dashain by the victory of truth to evil or say Ram to Ravan and offerings and thereby the order is maintained in the Hindu society. Therefore the phrase "Hindu religion is the religion of fear" seems more relevant in real life. This manner or ideologies, perceptions, and values should be taught to the new members and old members should be rememorized so as they will be in the form of truth and against the evil or false. In Hindu society, festivals either manifestly or latently and either personally or publicly enforce the members to control their behaviors, to manage their roles, and socialize the cultural, religiousnorms and values. In the public sphere, the collective gathering, social interactions are not made of consumption, but celebration, intended for Gods and Goddesses: the crowd unites in worships and expressions of joy in one hand and another hand they socialized culturally how to worship God and Goddess by participating in festivals events. Personally, every house shelters a little, personal temple, and each day is the occasion to honor one God, but festivals will put this adoration in the public sphere; festivities are the occasion to transport its faith in dedicated temples full of joy, beliefs, and socializations of it. In family level, the festivals are also made of their meetings and bring these concepts of share with family, affections, and in a move back to closest relatives: this phenomenon reveals the importance of celebrations by the scope of socialization of cultural values, norms, attitudes through participating publicly to develop their personality in the respective cultural context.

Similarly, other festivals also act as likewise to maintain the social order, social harmony, social cohesion, and solidarity despite there are the social tensions, social stresses, and social conflicts prevailing. In a way festivals either offer better, and healthier meals with offering Tika, wishes, blesses, and some money from elder ones. Family then is the social unit of imparting values, norms. The festival like Dashain in present context is not so far stands as a festival only it is a kind of learning social behavior, relationships, network, interaction through participation in the mechanism and processes of festival to control the social members. In a way, festival helps to narrow down the gap between family members, reduce tensions and strengthen the harmony, solidarity, and cohesion

\section{Conclusions}

It is found that the society, socialization and social order through the Hindu festivals in Nepal is a kind of ethnographic study on various cultural festivals in which festivals act as mechanism to regulate, socialize and control the life of people in a way in micro-level through the laws of religions, customs, and culture. Festivals also help their members, participants, observers to take part in the social sphere; public places also help to construct and build their perceptions, their personalities in respective cultural contexts and society. In such a situation, social interactions, socialization plays a vital role for them. It is found that Dashain and Tihar, along with other festivals, are playing a significant role in the social, religious, cultural, interactional, 
psychological spheres in either personal or social level for all.

It is also found that the specific cultural customs, organization, institutions, their parts, elements, and their interrelationship, interdependence or interplay should be studied by using integrated approaches to perform the task to maintain the total system are a function. Parallel with the idea of Augusta Comte (1976) and Herbert Spencer(1971)- as the societies should be studied as a whole - a system of interrelated parts.. Such functional analysis tries to identify the "institutions" that needed to fulfill the vital functions or "needs" necessary to keep the organism "alive" which consists of a number of interrelated and interdependent parts. A defect in one fails in another similarly, as society has a structure which is made up of several interrelated and interdependent parts such as the economy, caste, marriage, family, kinship, religion, festivals, whose functions contribute to the stability of the social system.

It is found that festivals offer the social harmony, solidarity, integration through socialization and such entertainment; works as a mechanism of conflict resolution in socio-cultural, religious, ecological, economically, linguistically, and in terms of caste ethnicity diverse country like Nepal. Finally, whole festivals of Hindus in Nepal are not a simple entity; they are complex whole through which participants (signifier) and observers (signified) the socio-cultural, political, religious, familial, emotional, recreational, etc. messages (messages of solidarity, transactions, cohesion, harmony and integrity through socialization) they that passes, and observer perceive such messages through the processes, mechanism, entertainment of festivities, and various celebrations within and between diverse generations, caste, ethnicity, economy, ecology, family, kin or say society and culture in a term. Such festivals promote the whole members by offering fests, meals, tika, prasad, blesses, wishes, sharing, feelings, emotions manifestly and they exchange love, affection, respects among all stakeholders of Patri-kin's, and their communities latently socialize to obey the norms, rules, regulations, values in behaves of the members of that society to maintain the relationship for the stability of their society in dynamic cultural world.

\section{ACKNOWLEDGEMENT}

Dahal, B.P. is thankful to those people who are organizing, participating the various festivals of Hindu cultures in Kathmandu Valley.

\section{References Références Referencias}

1. Bista, D. B. (1991). Fatalism and Development: Nepal's Struggle for Modernization. Calcutta: Orient Longman.

2. Bista, D.B. (1967). The People of Nepal. Ratna Pustak Bhandar, Kathmandu.
3. CBS, (2013). National Population and Housing Census 2011. Kathmandu; Ministry of Health and Population, Kathmandu, Nepal,

4. Comte, A. (1976). The Foundation of Sociology. ed. K. Thompson; London: Nelson.

5. Cooley, C.H. (1998). On Self and Social Organization, (ed.) Schubert Hans-Joachim, Chicago: University of Chicago Press.

6. Craib, I. (1997). Classical Social Theory. London; Oxford University Press,

7. CSRC (2012). Land Reform Monitoring Indicator, Nepal. Kathmandu: Community Self Reliance Center (CSRC).

8. Durkheim, E. (1947). The Elementary Forms of the Religious Life. Glencoe, III: Free Press (originally published in 1912).

9. FAO (2008). The State of Food and Agriculture, Rome: Food and Agricultural Organization (FAO) of the United Nations.

10. Feuerbach, L. (1957) [1893]. The Essence of Christianity. ( $3^{\text {rd }}$ ed.). London: Kegan Paul, Trench, Trübner \& Co.; New York: Harper \& Row (Harper Torchbooks).

11. Gluckman, M. (1954). Rituals of Rebellion in SouthEast Africa. Manchester: Manchester University Press.

12. Karve, I. (1953). Kinship Organization in India. Asia, Bombay,

13. Mead, G.H. (1938). Mind, Self and Society. Chicago; Chicago University Press.

14. Niroula, G. S., \& Thapa, G. B. (2007). Impact of Land Fragmentation on Input Use, Crop Yield and Production Efficiency in the Mountains of Nepal. Land Degradation and Development, 18: 237-248.

15. Raines, J. (2002). Introduction; Marx on Religion (Marx, Karl). Philadelphia: Temple University Press. Page 5-6.

16. Sapkota, K. (2004). Gender Perspectives on Periurban Agriculture in Nepal. UA-Magazine, 2004: 38-39.

17. Shrestha, B. (2011). Land Development Boom in Kathmandu Valley (Commercial Pressure on Land Issues). Kathmandu: CDS and Rome, ILC.

18. Spencer, H. (1971). Structure, Function and Evolution. ed. Andreski; London: Nelson.

19. Turner, V (1968a). The Drums of Affliction; A Study of Religious Processes Among the Ndembu of Zambia. Oxford: Clarendon Press.

20. Turner, V (1968b). Myth and symbol. In International Encyclopedia of the Social Sciences, ed. by D. Sills, 576-582, New York: Macmillan \& The Free Press.

21. Turner, V (1977a). Symbols in African Ritual, In Symbolic Anthropology: A Reader in the Study of Symbols and Meanings. ed. by J. L. Dolgin, D. S. Kemnitzer and D. M. Schneider, 183-194, New York: Columbia University Press. 
22. Turner, V. (1967). The Forest of Symbols: Aspects of Ndembu Ritual. Ithaca, London: Cornell University Press.

23. Turner, V. (1976). Ritual, Tribal and Catholic. Worship 50: 504-526.

24. Tylor, Edward B. 1958 [1873, 1871]. The Origins of Culture and Religion in Primitive Culture. Volumes I and II of the 1873 edition of Primitive Culture, New York: Harper \& Brothers.

25. Van Hung, P., MacAulay, G., \& Marsh, S. (2007). The Economics of Land Fragmentation in the North Vietnam. The Australian Journal of Agricultural and Resource Economics, 51:195-211.

26. Weber, M. (2009) [1904/1958]. The Protestant Ethic and the Spirit of Capitalism. Norton Critical Editions.

27. Wu, Z., Liu, M., \& Davis, J. (2005). Land Consolidation and Productivity in Chinese Household Crop Production. China Economic Review, 16:28-49. 